\title{
Domestic water consumption pattern by urban households
}

Amarasingam Narmilan ${ }^{1}$, Narmilan Puvanitha ${ }^{2}$, Gnanachelvam Niroash ${ }^{3}$, Muthucumaran Sugirtharan ${ }^{4}$, and Ratnarajah Vasssanthini ${ }^{5}$

1,3,5 Department of Biosystems Technology, Faculty of Technology, South Eastern University of Sri Lanka

${ }^{2}$ Department of Agriculture, Hardy, Sri Lanka Institute of Advanced Technological Education.

${ }^{4}$ Department of Agricultural Engineering, Faculty of Agriculture, Eastern University, Sri Lanka

ABSTRACT

*Corresponding Author Email: *narmilan@seu.ac.lk

Water has been recognized as one of the most significant natural resources and crucial for health and wealth. The increased demand for water has imposed pressure on the water supply system, which has led to environmental problems such as over-exploitation of water resources and breaks in the balance of the ecosystem. Determining the behavior of domestic water consumers can facilitate a more proactive approach to water demand management, and serves as the foundation for the development of any intervention strategies that seek to bring about sustained and substantial reductions in domestic water consumption. This study tried to investigate household water consumption patterns and management practices along with comparing the effectiveness of different water management measures on reducing the water deficit of the district. The primary data was collected through a questionnaire survey from 75 households belonging to the urban area in Batticaloa District in Manmunai Pattu, Sri Lanka. The data were analyzed both quantitatively and qualitatively. The findings show that people with higher incomes in urban areas are using more water than people with lower incomes. The water usage depends on the living standards, family size, age, and education level of household members and the number of taps present in the household. It is believed that the results of the study would be beneficial for domestic water consumption in urban Batticaloa.

KEYWORDS: Batticaloa; Efficiency; Household; Water consumption; Water deficit

\section{INTRODUCTION}

Water has been played a crucial role in the location, function, and growth of communities. Water is essential to life and it serves as the base for the social and economic development of any country in the world (Omvir and Sushila, 2013). The United Nations has projected world population would increase by an additional two billion $\left(2 \times 10^{9}\right)$ people by the year 2030 (Postel, 2000). The World Health Organization (WHO) defined domestic water as the water used for all domestic purposes including drinking, bathing, and food preparation. Domestic water consumption is a significant component of the total water use and it varies according to the living standards of the consumers in urban and rural areas (Mohammed and Sanaullah, 2017). Water is used for various indoor purposes among which are bathing, washing clothes, drinking, flushing the toilets, washing plates, washing fruits and vegetables, brushing teeth, cooking, performing ablution, and shaving (Olasumbo, 2006). Providing adequate and improved drinking water is an increasingly significant albeit a daunting challenge for authorities, development agencies, and water sector organizations, more especially in countries with rapidly growing populations. Improved drinking water refers to water sourced from a tap located within premises or yard/plot, a public standpipe, a tube well, a protected dug well or spring, and rainfall (UNICEF/WHO, 2015).

Population growth, expansion of business activity, urban development, water pollution, climate change, and drought have contributed to increased water scarcity in many parts of the world. It is estimated that a fifth of the world's population live in areas of physical water scarcity, where there is not enough water to meet all demands. One-third of the world's population does not have access to clean drinking water. Further one-fourth of the world's people live in areas of economic water scarcity, where poor management makes it impossible for authorities to satisfy the demand for water (Molden, 2007). The household water consumption is determined by quite a few factors, such 
86

as climate, seasonality, socioeconomic characteristics, and socio-demographics. In this study, only the socio-demographic factors are taken into account. The majority of research projects have focused on highlighting the current water shortage and the increased use by the residential sector. However, a lack of studies on household water consumption is observed when meeting household water demand is one of the main goals of various policy interventions and programme guidelines on drought mitigation or domestic water management strategies. The present study aims at analyzing the impacts of household socio-economic conditions on various aspects of domestic water consumption in urban Batticaloa in Manmunai Pattu, Sri Lanka.

\section{METHODOLOGY}

A survey was conducted on household water consumption in urban Batticaloa area. This survey includes the development and distribution of a questionnaire to the households of urban Batticaloa. A Simple random sampling technique was followed to select households such that each household has an equal probability of being included in the study. Besides, more than half of the respondent households do not engage in water conservation at their households at present due to continuous access to water through their water source.

\section{Flow rate experiment}

The results of the semi-structured interview showed that the sales assistants in water appliances shops were not sure about the flow rate of taps and showerheads. They identified some waterefficient products but were not sure how much water could be saved. Product instruction only showed the size and features of the product, not including the flow rate. The varying flow rates of different appliances could affect water consumption in different households. So, the flow rate is an important indicator to understand the amount of water use at home. From the literature review, it was found that the flow rate (tap and showerhead) could be measured through a simple experiment. The test procedure was based on the Green Venture website: how to conduct a flow rate test, 2007(Green Venture, 2007). The test instruments included a stopwatch (Mobile phone), a container with measurements on the side, the maximum measurement being 1.5 litres, and a calculator. The main procedures were as follows:

1) The empty container was placed under a tap or showerhead; the tap or the showerhead was turned on to its highest flow rate. The stopwatch was started at the same time. When the water reaches 1 litre, the watch was stopped and the time was recorded.

2) The flow rate was calculated. For example, to fill one litre container takes 5.8 seconds, $5.8 \mathrm{sec}=0.1$ $\mathrm{min}$, the flow rate $=1$ litre 0.1 minute $=10$ litre $/$ minute

3) This procedure was repeated twice for each test and the average number was used. 


\section{RESULTS AND DISCUSSION}

93 1. Demographic composition

94

Table 1: Demographic composition

\begin{tabular}{|c|c|c|c|c|c|}
\hline $\begin{array}{l}\text { Age of the } \\
\text { household head } \\
\text { (years) }\end{array}$ & Number & Percentage & Education & Number & Percentage \\
\hline Below 25 & 0 & 0 & Primary & 0 & 0 \\
\hline $25-35$ & 8 & 10.7 & Intermediate & 15 & 20.0 \\
\hline $36-45$ & 16 & 21.3 & Advanced & 36 & 48.0 \\
\hline $46-55$ & 21 & 28.0 & Higher & 22 & 29.3 \\
\hline $56-65$ & 23 & 30.7 & None & 2 & 2.7 \\
\hline Above 66 & 7 & 9.3 & Total & 75 & 100.0 \\
\hline Total & 75 & 100.0 & & & \\
\hline $\begin{array}{l}\text { Ownership of } \\
\text { the House }\end{array}$ & & & $\begin{array}{l}\text { Living standard of } \\
\text { the family }\end{array}$ & & \\
\hline Own & 64 & 85.3 & Poor & 2 & 2.7 \\
\hline Rented & 11 & 14.7 & Medium & 59 & 78.7 \\
\hline \multirow[t]{2}{*}{ Total } & 75 & 100 & Rich & 14 & 18.7 \\
\hline & & & Total & 75 & 100.0 \\
\hline $\begin{array}{l}\text { Occupation of } \\
\text { Household head }\end{array}$ & & & $\begin{array}{l}\text { Average Monthly } \\
\text { Income of } \\
\text { Household }\end{array}$ & & \\
\hline Government & 29 & 38.7 & Below10,000 Rs & 0 & 0 \\
\hline Private/NGO & 11 & 14.7 & $10,001-15,000 \mathrm{Rs}$ & 2 & 2.7 \\
\hline Business & 7 & 9.3 & $15,001-20,000 \mathrm{Rs}$ & 2 & 2.7 \\
\hline Farmer & 4 & 5.3 & $20,001-25,000 \mathrm{Rs}$ & 6 & 8.0 \\
\hline $\begin{array}{l}\text { Day-wage } \\
\text { labour }\end{array}$ & 4 & 5.3 & $25,001-30,000 \mathrm{Rs}$ & 12 & 16.0 \\
\hline Others & 20 & 26.7 & $30,001-40,000 \mathrm{Rs}$ & 11 & 14.7 \\
\hline \multirow[t]{3}{*}{ Total } & 75 & 100.0 & $40,001-50,000 \mathrm{Rs}$ & 13 & 17.3 \\
\hline & & & Above 50,000 Rs & 29 & 38.7 \\
\hline & & & Total & 75 & 100.0 \\
\hline \multicolumn{6}{|l|}{ Family size } \\
\hline 2 & 2 & 2.7 & & & \\
\hline 3 & 26 & 34.7 & & & \\
\hline 4 & 27 & 36.0 & & & \\
\hline 5 & 11 & 14.7 & & & \\
\hline 6 & 6 & 8.0 & & & \\
\hline 7 & 3 & 4.0 & & & \\
\hline Total & 75 & 100 & & & \\
\hline
\end{tabular}

Different Statistical analyses were carried out with the assistance of IBM SPSS Software (Version 25.0) and the data were presented. Simple descriptive measures, analysis for variance, post hoc tests, and multivariate regression analysis were applied. The principal component analysis was used to assess the socio-economic status of households based on the assets they hold. Before any parametric statistical analysis, data were assessed for normality. The demographic composition of 
the sample households/Social status of farmers in the survey community is shown in Table 1 . The age distribution and the education level of the heads of these households are shown in Table 1. Around $30.7 \%$ of households' heads are aged between 56 to 65 and $28 \%$ are aged from 46 to 55 years while those who in $36-45$ age accounted for $16 \%$ of the total respondents. With regards to the household heads whose age between $25-35$ years and below 66 years were almost similar by having $8 \%$ and $7 \%$ respectively. However, there were no household heads observed below 25 aged groups. The survey showed that around half of the respondents (48\%) have completed their advanced level of education while those who have received their higher education and intermediate level of education are $22 \%$ and $15 \%$ respectively. However, only $2 \%$ of them were uneducated and there are no individuals who attained only primary education. The result in Table 1 shows that $85.3 \%$ of household heads have their own house while $14.7 \%$ of respondents reside in rented houses. In terms of living standards of the respondent's family, it was observed that a higher percent (73.70\%) of the family whose living standard is medium followed by rich families (18.7\%) while the poor were accounted for $2.7 \%$. The number of household size is one of the basic demographic characteristics of a household. Distribution of respondents according to household size shows that the majority (36\%) of the families had 3 to 6 members in their houses while 14\% of them had 5 members and those who have the members of 6,3 , and 2 in $8 \%, 4 \%$, and $2 \%$ respectively. According to the survey, the occupations of family heads found to be involved in the government sector (38.7\%), other kinds of jobs $(20 \%)$, private or NGOs $(14.7 \%)$, and the rest of them were engaged in business $(9 \%)$, farming (5.3\%) and daily labour work (5.3\%).

\section{Age of household members}

Water usage is also affected by age of household members. The water usage behaviors can be quite different among different ages of household members. Households with children could be expected to use more water. Youngsters might use water less carefully, e.g. taking more showers, doing more frequent laundering, while retired people might be much thriftier (Nauges and Thomas, 2000). Elder people use less water than younger people. Nauges and Thomas (2000) support this and observe that communities with more seniors have lower water consumption, and similar results have been found by (Martínez-Espiñeira 2002, Martins and Adelino 2007, Musolesi and Nosvelli 2007). But Schleich and Hillenbrand (2009) found the opposite, that the elder people use more water because retired people spend more time at home and gardening. After all, children use less water for washing and hygiene than adults, or because health reasons may force older people to use the bathroom more frequently.

\section{Living standards}

Table 2: Correlation between living standards - total usage

\begin{tabular}{llrr}
\hline & & Living standards & Total usage \\
\hline \multirow{2}{*}{ Living standards } & Pearson Correlation & 1 & $.825^{* *}$ \\
& Sig. (2-tailed) & & .000 \\
\multirow{5}{*}{ Total usage } & $\mathrm{N}$ & 75 & 75 \\
& Pearson Correlation & $.825^{* *}$ & 1 \\
& Sig. (2-tailed) & .000 & \\
& $\mathrm{~N}$ & 75 & 75 \\
\hline
\end{tabular}

**. Correlation is significant at the 0.01 level (2-tailed).

Total domestic water consumption is positively correlated with living standards as $p<0.01$ (Table 2). This was supported by Syme et al. and Loh and Coghlan. This result is attributed to the use of modern appliances and a lack of knowledge of elders. People in developing countries spend more money on items that consume more water such as dishwashers, washing machines, flushing toilets, and showers. People also tend to eat more meat as living standards increase, which also needs 
more water in its production. A variable that has a positive effect on household water consumption is the number of people in a residence (Hanke and Maré 1982). Total water usage of the study population was 12732.5 liters and Per capita, water usage was 169.8 liters.

\section{Income level}

The correlation between water consumption and income level of the survey community is shown in Table 3.

Table 3: Correlation between water consumption and income level

\begin{tabular}{llll}
\hline & & Income & Total usage \\
\hline Income & Pearson Correlation & 1 & $.968^{* *}$ \\
& Sig. (2-tailed) & & .000 \\
& $\mathrm{~N}$ & 75 & 75 \\
Total & Pearson Correlation & $.968^{* *}$ & 1 \\
usage & Sig. (2-tailed) & .000 & \\
& $\mathrm{~N}$ & 75 & 75 \\
\hline
\end{tabular}

**. Correlation is significant at the 0.01 level (2-tailed).

It is shown that the total domestic water consumption is positively correlated with income level $(p<0.01)$. High water consumption may due to the high living standard of the survey community (Table 3), as a high level of income is associated with high living standards. This may mean a higher number of water-consuming appliances and a higher probability of high-water usage for watering large garden areas. This was supported by Guhathakurta and Gober, (2007) who indicate that income rises result in a corresponding increase in water consumption. Dalhuisen, 2003, stated that though the water consumption is increased with income, it is not a proportional increase. Usage of western-style bathtubs, dishwashers, and washing machines in high-income households also attribute to high-water consumption. The literature by Kenney, 2008 has also reported higher water consumption per capita for higher-income homes.

\section{Education level}

The correlation between water consumption and education level of the survey community is shown in Table 4.

Table 4: Correlation between water consumption and education level

\begin{tabular}{llll}
\hline & & Education & Total usage \\
\hline Education & Pearson Correlation & 1 & $-.873^{* *}$ \\
& Sig. (2-tailed) & & .000 \\
& $N$ & 75 & 75 \\
\multirow{5}{*}{ Total usage } & Pearson Correlation & $-.873^{* *}$ & 1 \\
& Sig. (2-tailed) & .000 & \\
& $\mathrm{~N}$ & 75 & 75 \\
\hline$* *$. Correlation is significant at the 0.01 level (2-tailed).
\end{tabular}

The education level also influences the water consumption in a household. It is shown that the total domestic water consumption is negatively correlated with education level as $p<0.01$ (Table 4). Educated people are more conscious about the increasing water scarcity and they literate their younger generation to use the water resources efficiently. It has been shown in (Millock and Nauges, 2010) that the education level is positively correlated with lower water consumption and higher 
water conservation behaviors which would cut down the household total water consumption. Educational campaigns teach easy ways to conserve water and increase feelings of self-efficacy. Targeted educational campaigns about environmental conservation behaviors aimed at elementary students in the US are effective in increasing those behaviors within their households (Woollam et al, 2006). Keshavarzi et al, 2006 reported that the low level of education of elders regarding environmental matters leads them to consume more water than do younger people. But in contrast, Collins et al, 2003 stated that older people tend to use less water because of traditional practices of water usage (washing hands, showering, and sharing water among family members) and their unfamiliarity with water appliances.

\section{Number of taps}

Table 5: Correlation between the number of taps and total usage

\begin{tabular}{llll}
\hline & & Number of taps & Total usage \\
\hline Number of taps & Pearson Correlation & 1 & $.951^{* *}$ \\
& Sig. (2-tailed) & & .000 \\
\multirow{5}{*}{ Total usage } & $\mathrm{N}$ & 75 & 75 \\
& Pearson Correlation & $.951^{* *}$ & 1 \\
& Sig. (2-tailed) & .000 & \\
& $\mathrm{~N}$ & 75 & 75 \\
\hline$* *$ Correlation &
\end{tabular}

**. Correlation is significant at the 0.01 level (2-tailed).

The number of taps also influences the water consumption in a household. Table 5 shows that the total domestic water consumption is positively correlated with the number of taps as $p<0.01$. It is proved from the results that there was a great impact on water consumption due to the increased number of taps. Also, the increase in water consumption could be attributed to the pipe diameter and water flow rate (Englart and Jedlikowski, 2019).

\section{Household size}

Table 6: Correlation between family size and total usage

\begin{tabular}{llrr}
\hline & \multicolumn{2}{c}{ Family size } & Total usage \\
\hline Family size & Pearson Correlation & 1 & $.950^{* *}$ \\
& Sig. (2-tailed) & 75 & .000 \\
& $\mathrm{~N}$ & $.950^{* *}$ & 75 \\
Total usage & Pearson Correlation & .000 & 1 \\
& Sig. (2-tailed) & 75 & 75 \\
\hline$* *$. Correlation is significant at the 0.01 level (2-tailed). & &
\end{tabular}

Table 6 shows that the total domestic water consumption is positively correlated with household size as $p<0.01$. The number of household members affects the amount of water used in a house (Gaudin, 2006). Households with more family members used larger quantities of water. Arbus, et al (2004) found that water consumption increases with the household size, though it is not a proportional increase. However, household size was found to be an insignificant factor in water usage at the domestic level (Guhathakurta and Gober, 2007). A household of a large size normally uses more appliances with greater frequency, resulting in more water usage than a small size household. Numerous studies have shown a strong correlation between the age of household head and net family size and water consumption (Arouna and Dabbert, 2010; Syme et al, 2004). 


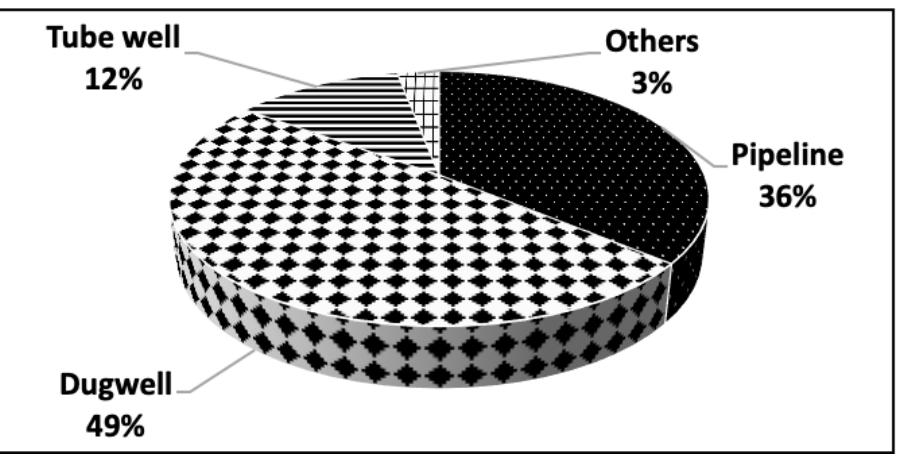

Figure 1: sources of the water supply of the households

The chart (Figure 1) illustrates the different sources of the water supply of the households. It was clear that around half of the proportion of the households (49\%) receive the pipeline water followed by tube well usage to a level of $36 \%$ while those who use water from dug well accounted for $12 \%$. The lowest amount (3\%) of respondents got water from other sources like lakes, rivers, and ponds. A similar result was reported by Tadesse et al. (2013) and Mahama et al. (2014). The choice of water source is strongly influenced by several household characteristics. Local households seem to have adopted different practices for accessing alternative water sources rather than dug well alone to meet their diverse needs. Most households are dependent on private wells. But water sources and their uses changed significantly between the wet and dry seasons (Elliott et al, 2017). The most common household water sources were taps and well (Casanova et al, 2012).

9. Drinking water

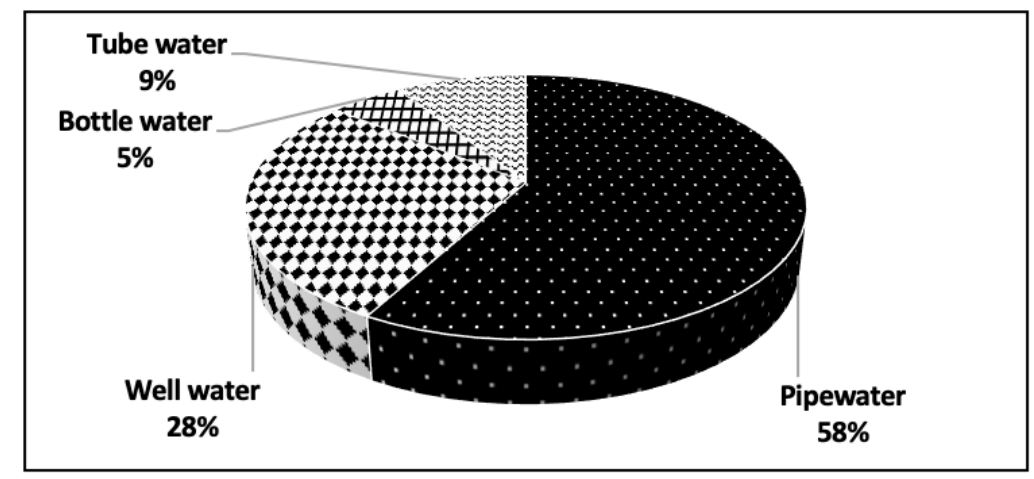

Figure 2: sources of drinking water of the households

The figure summarizes the percentage use of drinking water from a different source of water supply. Overall, the highest amount (58\%) of drinking water was collected using the pipeline. Drinking water consumption from well water accounts $28 \%$ of the total population while the tube well water and bottled water were the lowest quantity of water which is utilized for drinking purposes among the households for $9 \%$ and $5 \%$. Piped water supply was the most common drinking-water source in urban areas. This parallels the Nketiah-Amponsah et al. (2009) observed that access to a piped drinking water source is higher compared to other types of drinking water sources. Bottled water consumption is low due to the high price. Results of a study by Vásquez, 2017 indicated that bottled 
water consumption was positively associated with health risk perceptions, household income, and education and market access. Household size negatively impacted the likelihood of consuming bottled water.

\section{Family practice adopted in the preparation of drinking water}

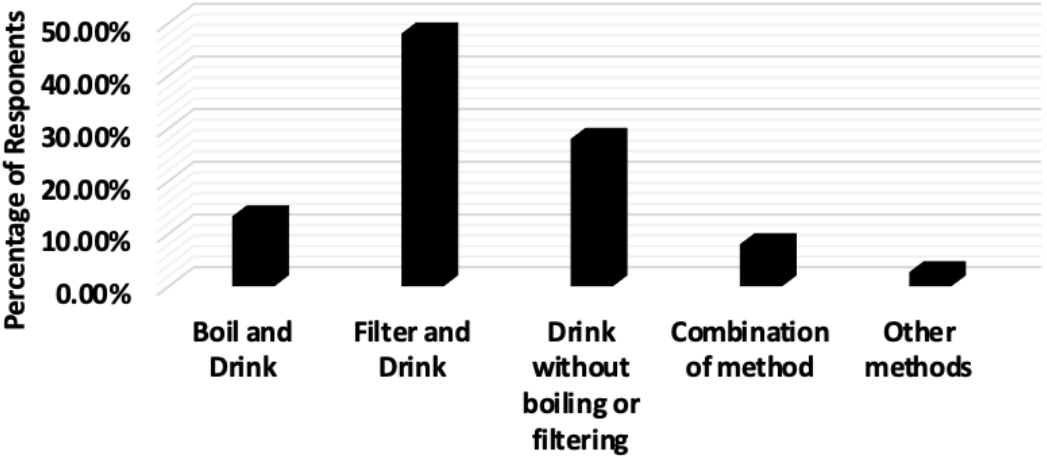

Figure 3: Family practice adopted in the preparation of drinking water

Figure 3 shows the family practice adopted in the preparation of drinking water. Most of the respondents (48\%) were practicing filter and drinking methods but $28 \%$ of the families were adopted to drinking the water without boiling or filtering. In terms of the boiling and drinking method, only about $13 \%$ of families were using this method. However, only about $8 \%$ of respondents were using the combination method and $2.7 \%$ were using other methods when preparing the drinking water. Boiling and filtering are the most common methods used in households for purifying water. Clasen et al, 2008 stated that boiling is a relatively expensive method, and Wolf et al, 2014 stated that filtering by cloth is an ineffective method. Gilman and Skillicorn, 1985 stated that the cost of boiling may be expensive for many low-income populations. Francis et al, 2015 observed the frequency of filtering water for children is higher than adults. However, studies have shown that, although necessary and potentially having a positive health impact, households do not regularly use HWT (Brown and Clasen, 2012). Filtering was more common among user households than any form of treatment (Casanova et al, 2012).

\section{Irrigation}

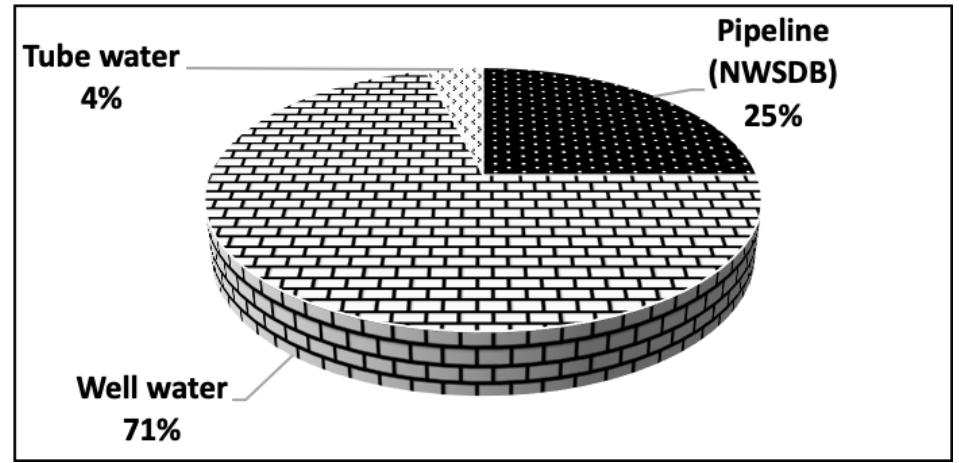


It was clear that the highest percentage $(\mathbf{7 1 \% )}$ of water from well water has been used for irrigation purposes among the households while the least amount of water for irrigation has been drawn up using tube well. However, $25 \%$ of the water was collected from well water.

\section{Water-related appliances in the home}

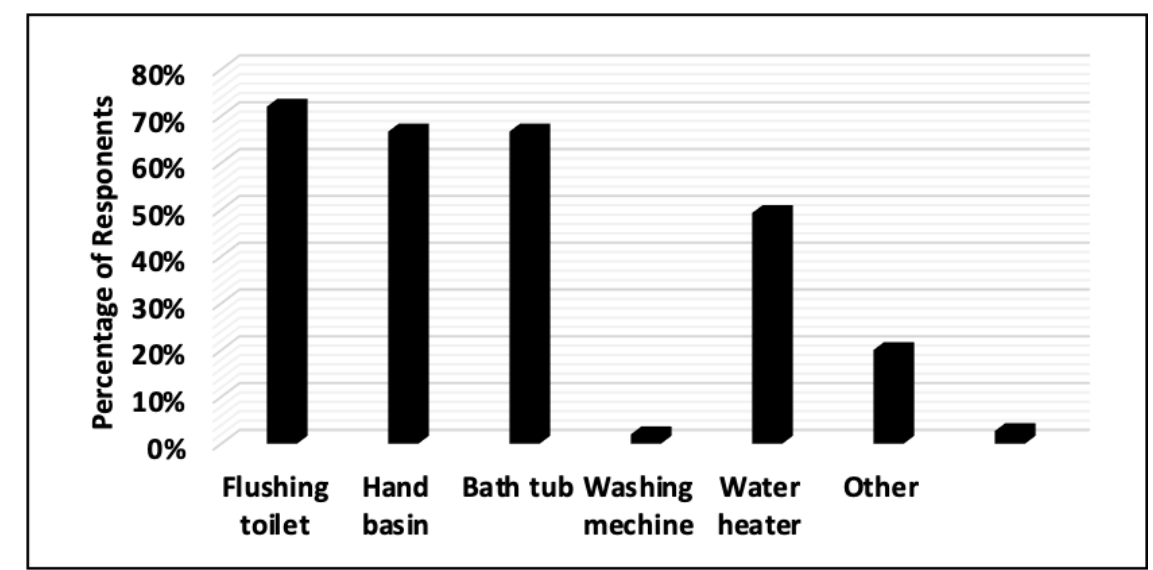

Figure 5: usage of water-related appliances in the home

The chart illustrates the patterns of water use by households. It was clear that the highest amount (72\%) water has been used for showers and baths for daily use by households while $66.7 \%$ of total water of household is used in toilet flushing and personal hygiene, especially for hand washing. Nearly half of the proportion of water is utilized for washing machines. It was also found that small quantities needed for water heaters, bathtub and other needs using $20 \%, 12 \%$, and $2.7 \%$ respectively. Literature by Beal and Stewart argues that high volumes of water are consumed by teenagers for showers. Shaban and Sharma, (2007) found that bathing, flushing, clothes washing, and utensil washing accounting for much higher water use in households. Modern changes in lifestyle all potentially contributing to the increase in water use for bathing and showering (BelloDambatta, 2014). Also, en-suite bathrooms and changes in lifestyle are contributing to the trend towards using significantly more water for showering (Shaban and Sharma, 2007)

\section{CONCLUSION}

The increased demand for water has imposed a pressure on water supply system, which has led to environmental problems such as over-exploitation of water resources and breaks in the balance of the ecosystem. Determining the behavior of domestic water, consumers can facilitate a more proactive approach to water demand management, and serves as the foundation for the development of any intervention strategies that seek to bring about sustained and substantial reductions in domestic water consumption. This paper presented the findings of a domestic water consumption questionnaire survey containing over 40 questions carried out in urban Batticaloa in Manmunai Pattu, Sri Lanka. Simple random sampling technique was followed to select households and the statistical package IBM SPSS 25.0 was used for data entry and analysis of the data.

This study showed that high income level as well as living standards increased total domestic water consumption. It was shown that elder people use less water than younger people in general. Total 
domestic water consumption for household uses indicated that, highest amount of $(72 \%)$ water has been used for showers and bath compared to toilet flushing, personal hygiene and cloth washing. Family size and number of taps in a household were found to be important indicators in estimating household water consumption; it was shown that families with many members and high number of taps have higher water consumption in general. Results showed that the total domestic water consumption is negatively correlated with education level. The findings of this study concluded that, the socio-economic condition of the households impacts on various aspects of domestic water consumption in urban Batticaloa in Manmunai Pattu, Sri Lanka.

\section{REFERENCE}

Arbus, F,; Barbern,R,; Villana, I., (2004). Price impact on urban residential water demand: A dynamic panel data approach, Water Resources Research, 40(11).

Arouna, A,; Dabbert S., (2010). Determinants of domestic water use by rural households without access to private improved water sources in Benin: A seemingly unrelated Tobit approach. Water Resour Manage 24: 1381-1398. http://hdl.handle.net/10.1007/s11269-009-9504-4

Beal, C,; Stewart, R. A., (2011). South East Queensland residential end use study: final report. Urban Water Security Research Alliance Technical Report No. 47.

Bello-Dambatta, A,; Kapelan, Z,; Butler, D., (2014). Impact assessment of household demand saving technologies on system water and energy use, British Journal of Environment and Climate Change, 2014; ISSN: 2231-4784, Vol.: 4, Issue: 2 (April-June).

Bello-Dambatta, A,; Kapelan, Z,; Butler, D,; Oertlé, E,; Hugi, C,; Jelinkova, Z,; Becker, N,; Hochstrat, R,; Rozos, e,; Makropoulos, C,; Wintgens, T., (2010). Priorities of current and emerging water demand management technologies and approaches, EU FP7 TRUST project report. https://doi.org/10.9734/BJECC/2014/4533

Bole, R., (2006). Life-cycle optimization of residential clothes washer replacement. MSc Thesis. University of Michigan Ann Arbor. http://css.snre.umich.edu

Brown, J,; Clasen, T., (2012). High adherence is necessary to realize health gains from water quality interventions. PLoS One, 7:1-9. https://doi.org/10.1371/journal.pone.0036735

Casanova, L.M,; Walters, A,; Naghawatte, A,; Sobsey, M. D., (2012). Factors affecting continued use of ceramic water purifiers distributed to tsunami-affected communities in Sri Lanka. Tropical Medicine and International Health. 17(2): 1361-1368. https://doi.org/10.1111/j.1365$\underline{3156.2012 .03082 . x}$

Clasen, T,; McLaughlin, C,; Nayaar, N,; Boisson, S,; Gupta, R,; Desai, D,; Shah, N., (2008). Microbiological effectiveness and cost of disinfecting water by boiling in semi-urban India. Am J Trop Med Hyg; 79:407-13. https://doi.org/10.4269/ajtmh.2008.79.407

Collins, J,; Thomas, G,; Willis, R,; Wilsdon, J.m (2003) Carrots, sticks and sermons: influencing public behaviour for environmental goals. Report version 4.0. Demos and Green Alliance. DEFRA.

CSE, Roadmap for rating system for water efficient fixtures - A way to sustainable water management in India, Centre for Science and Environment, 2010; New Delhi.

Dalhuisen, J.M.; Florax, R. J. G. M,; de Groot, H. L. F,; Nijkamp, P., (2003). Price and income elasticities of residential water demand: a meta-analysis. Land Economics, 79(2), 292-308. 
Department for Environment, Food and Rural Affairs (Defra). Guidelines to Defra's GHG conversion factors. 2010; Available on: http://archive.defra.gov.uk/environment/business/reporting/pdf/passenger-transport.

EA. Water efficiency in the south east of England retrofitting existing homes. Environment Agency, 2007; Bristol, UK.

Elliott, M.; MacDonald, M. C.; Chan, T.; Kearton, A.; Shields, K. F.; Bartram, J. K.; Hadwen, W. L., (2017). Multiple household water sources and their use in remote communities with evidence from Pacific Island Countries. Water Resources Research, 53, 9106-9117

Englart, S,; Jedlikowski, A., (2019)The influence of different water efficiency ratings of taps and mixers on energy and water consumption in buildings. SN Appl. Sci. 1, 525.

Fan, L,; Liu, G,; Wang, F,; Geissen, V,; Ritsema, C. J,; Tong, Y., (2013). Water Use Patterns and Conservation in Households of Wei River Basin, China: Resources, Conservation and Recycling Journal, (74):45 - 53.

Francis, M.R,; Nagarajan, G,; Sarkar, R,; Mohan, V.R,; Kang, G,; Balraj, V., (2015) Perception of drinking water safety and factors influencing acceptance and sustainability of a water quality intervention in rural southern India. BMC Public Health 15, 731. https://www.zealbots.com/1072158/1072158

Gaudin, S., (2006). Effect of price information on residential water demand, applied economics, 38(4), pp. 383-393. https://doi.org/10.1080/00036840500397499

Gilman, R.H,; Skillicorn P., (1985). Boiling of drinking-water: can a fuel-scarce community afford it? Bull WHO 63: 157-163.

https://www.ncbi.nIm.nih.gov/pmc/articles/PMC2536343/pdf/bullwho00084-0165.pdf

Guhathakurta, S,; Gober, P., (2007). The impact of the Phoenix urban heat island on residential water use, Journal of the American Planning Association, 73(3), pp. 317-329. https://doi.org/10.1080/01944360708977980

Kenney, D.S.; Goemans, C,; Klein, R.A,; Lowrey, J,; Reidy, K., (2008). Residential water demand management: lessons from Aurora, Colorado. Journal of the American Water resources Association, 44 (1):192-207.

Keshavarzi AR, Sharifzadehb M, Kamgar Haghighi AA, Amin S, Keshtkar Sh, et al. (2006) Rural domestic water consumption behavior: A case study in Ramjerd area, Fars Province, I.R. Iran. Water Res 40: 1173-1178.

Loh, M,; Coghlan, P., (2003). Domestic water use study: In Perth, Western Australia 1998-2001. Water Corporation of Western Australia, Australia.

Mahama, A. M,; Anaman, K.A,; Osei-Akoto, I., (2014). Factors influencing householders' access to improved water in low-income urban areas of Accra, Ghana. Journal of Water and Health Vol. 12, No.2, pp. 318-331.

Millock, K,; Nauges, C., (2010). Household adoption of water-efficient equipment: the role of socioeconomic factors, environmental attitudes and policy. Environmental Resource Economics, 46: pp. 539-565.

Mohammed, A.H,; Sanaullah, P., (2017). An Empirical Analysis of Domestic Water Sources, Consumption and Associated Factors in Kandahar City, Afghanistan. Resources and Environment Journal, 17(2): 49 to 61 . 
Molden, D., (2007). Water for food, Water for life: A Comprehensive Assessment of Water

373 Management in Agriculture. 2007.

374 https://www.iwmi.cgiar.org/assessment/files new/synthesis/Summary SynthesisBook.pdf

375 MTP. BNWAT06: Showers - water efficiency performance tests. 2010.

376 Nauges, C,; Thomas, A., (2000). Privately operated water utilities, municipal price negotiation, and

377 estimation of residential water demand: the case of France, Land Economics, 76(1), pp. 68-85.

Nketiah-Amponsah, E,; Aidam, P. W,; Senadza, B., (2009). Socio-economic determinants of sources of drinking water: Some insight from Ghana. Paper presented at the Conference on International Research on Food Security, Natural Resource Management and Rural Development, University of Hamburg, Germany

Olasumbo, M., (2001). Water Resources Management in Nigeria - Issues and Challenges in a New Millennium. Inaugural lecture delivered at the University of Agriculture, Ogun State.

Omvir, S,; Sushila, T., (2013). A Survey of Household Domestic Water Consumption Patterns in Rural 790.

Postel, S.L., (2000). Entering an Era of Water Scarcity: The Challenges Ahead. Ecological Application, 388 10(4):941-948.

Shaban, A,; Sharma, R. N., (2007). Water consumption patterns in domestic households in major cities in India, Economic and Political Weekly, Vol - XLII No. 23. use. Landscape Urban Plan 68: 121-128.

Tadesse, A,; Bosona, T,; Gebresenbet, G., (2013). Rural Water Supply Management and Sustainability: The Case of Adama Area, Ethiopia. Journal of Water Resource and Protection Vol. 5, pp. 208-221.

UNICEF/WHO., (2015). Progress on Sanitation and Drinking Water - 2015 Update and MDG Assessment. WHO Library Cataloguing-in-Publication Data, Geneva, Switzerland. empirical evidence from a small town in Guatemala. International Journal of Consumer Studies, 41: 199-206. https://doi.org/10.1111/ijcs.12327

Wolf J, Prüss-Ustün A, Cumming O, Bartram J, Bonjour S, Cairncross S, et al. (2014). Systematic 402 review: Assessing the impact of drinking water and sanitation on diarrhoeal disease in low- and 403 middle-income settings: systematic review and meta-regression. Trop Med Int Health. 19:928-42.

404 Woollam, T.; Griffiths, T,; Williams, K,; (2006). Do Children Take the Recycling Message Home? In 405 Proceedings of the Twenty-First International Conference on Solid Waste Technology and 406 Management, Philadelphia, PA, USA. 